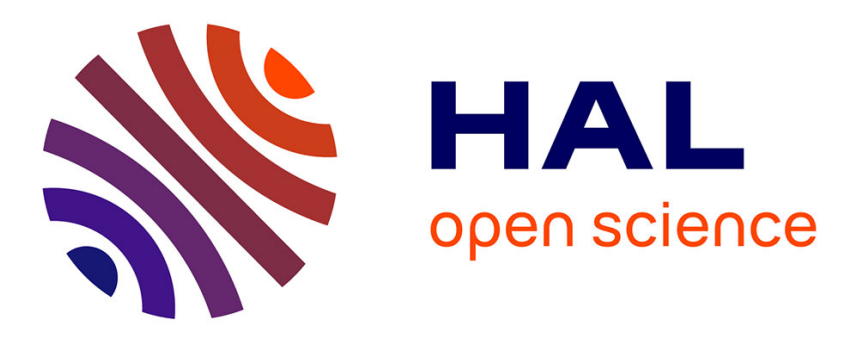

\title{
The rehabilitation of facial involvement in systemic sclerosis: efficacy of the combination of connective tissue massage, Kabat's technique and kinesitherapy: a randomized controlled trial
}

S. Maddali-Bongi, G. Landi, F. Galluccio, A. del Rosso, I. Miniati, M. L. Conforti, R. Casale, M. Matucci-Cerinic

\section{To cite this version:}

S. Maddali-Bongi, G. Landi, F. Galluccio, A. del Rosso, I. Miniati, et al.. The rehabilitation of facial involvement in systemic sclerosis: efficacy of the combination of connective tissue massage, Kabat's technique and kinesitherapy: a randomized controlled trial. Rheumatology International, 2010, 31 (7), pp.895-901. 10.1007/s00296-010-1382-9 . hal-00615342

\author{
HAL Id: hal-00615342 \\ https://hal.science/hal-00615342
}

Submitted on 19 Aug 2011

HAL is a multi-disciplinary open access archive for the deposit and dissemination of scientific research documents, whether they are published or not. The documents may come from teaching and research institutions in France or abroad, or from public or private research centers.
L'archive ouverte pluridisciplinaire HAL, est destinée au dépôt et à la diffusion de documents scientifiques de niveau recherche, publiés ou non, émanant des établissements d'enseignement et de recherche français ou étrangers, des laboratoires publics ou privés. 


\section{The rehabilitation of facial involvement in systemic sclerosis: efficacy of the combination of connective tissue massage, Kabat's technique and kinesitherapy - a randomized controlled trial}

Maddali Bongi $\mathrm{S}^{1}$, Landi $\mathrm{G}^{2}$, Del Rosso A ${ }^{1}$, Galluccio $\mathrm{F}^{1}$, Miniati ${ }^{1}$, Conforti ML ${ }^{1}$, Casale $\mathrm{R}^{3}$, Matucci Cerinic $\mathrm{M}^{1}$

${ }^{1}$ Department of BioMedicine, Division of Rheumatology, AOUC, Denothe Centre, University of Florence, Italy

${ }^{2}$ AMuRR (Associazione Multidisciplinare Riabilitazione Reumatologica), Blue Clinic Rheumatic Rehabilitation Center, Florence, Italy

${ }^{3}$ Neurophysiopathology Division, Fondazione "Salvatore Maugeri” I.R.C.C.S. Rehabilitation center, Montescano (Pavia, Italy)

\section{Correspondence to:}

Marco Matucci Cerinic, Dept. of BioMedicine, Division of Rheumatology,

Villa Monna Tessa, Viale Pieraccini 18, 50139 Firenze, Italy

Tel \& fax 390557949271

Email: cerinic@unifi.it 


\begin{abstract}
OBJECTIVE: In Systemic Sclerosis (SSc), face involvement causes functional loss as well as aesthetic changes and loss of the self-image. The aim of the work is to evaluate the efficacy of a rehabilitation program based on the combination of Kabat's technique, connective massage and kinesitherapy specifically conceived for the face of SSc patients. METHODS: 40 SSc patients were enrolled: 20 patients (interventional group) were treated for 9 weeks (twice a week, 1 hour per session) with a combined connective tissue massage, Kabat's technique, kinesitherapy and home exercise program and 20 patients (control group) were assigned only home exercise program. All patients were assessed at baseline (T0), at the end of the treatment (T1) and after 9 weeks of followup (T2). They were evaluated with SF-36, HAQ, modified Rodnan skin score, mouth opening in centimetres and Mouth Handicap in Systemic Sclerosis (MHISS) scale. RESULTS: At T1, both groups improved in mouth opening $(\mathrm{p}<0.05)$, but the improvement was maintained at $\mathrm{T} 2$ only in interventional group. In interventional group facial skin score ameliorated at $\mathrm{T} 1$, and maintained at T2 ( $<<0.05$ versus T0), while no change was observed in controls. In both groups, SF-36 and HAQ were not affected by the treatment. MHISS scale improved significantly in interventional group at T1 $(\mathrm{p}<0.001)$, while no change was found in controls. CONCLUSION: The combination of connective tissue massage, Kabat's technique, kinesitherapy and home-based exercises is more effective than an home exercise program alone in the rehabilitative treatment of SSc facial involvement.
\end{abstract}

Key words: Systemic Sclerosis, rehabilitation, connective tissue massage, Kabat method, physiotherapy; 


\section{Introduction}

Systemic Sclerosis (SSc) is characterised by induration of the skin and internal organs, by joint modifications and muscle impairment [1-5]. Skin fibrosis leads to tissue retraction and atrophy, and consequently to disability and reduction of patients quality of life (QoL).

Though most authors agree that specific SSc rehabilitation program can prevent and reduce disabilities deriving from skin and joint involvement [2], only few studies on this matter are available [6-9]. The involvement of face and oral tissues is a typical feature of SSc patients, that causes important aesthetic changes and impairment of the self-image [10]. The face becomes amimic, the cutaneous furrows disappear. Around the mouth, vertical wrinkling, due to skin retraction, develops and the nose becomes sharp.

Face changes also include thinning and reduction of mouth width (microcheilia) and opening (microstomia), also favoured by osteolysis of mandibular angles and by fibrosis of soft tissues. These modifications interfere with eating, speaking, oral hygiene measures, and dental treatment, thus deteriorating the quality of life of SSc patients $[6,11-15]$ and in most severe cases leading to surgical interventions, such as bilateral commissurotomies [6,11-15].

Rehabilitation management of microstomia, is mainly based on self administered home-based exercise program including mouth-stretching and oral augmentation exercises. This traditional approach has been shown to have some positive effect on mouth opening in SSc patients [6]. Preliminary results from our group suggested that the combination of connective tissue massage, Kabat's technique and a specific kinesitherapy program [8] can be usefully used for the treatment of facial involvement in SSc.

The aim of our work was to evaluate in SSc patients the efficacy of a rehabilitation program for the face based on the sequential combination of connective tissue massage, Kabat's technique, kinesitherapy and traditional home-based exercise program of mimic exercises versus home-based exercise program of mimic exercises alone. 


\section{Materials and methods}

Forty SSc patients, fulfilling ACR criteria [16] (6 males and 34 females; age: $57.28 \pm 11.33$ years; disease duration $9.4 \pm 4.3$ years), were enrolled from the outpatient clinic of the Department of Biomedicine - Division of Rheumatology, of the University of Florence. After a written informed consent, all patients underwent a clinical examination and were assessed according to international guidelines [17]. Entry criterion was face involvement assessed by a Rodnan skin score $\geq 1$ [18], no gender or age limits.

The presence of secondary Sjögren syndrome was evaluated by the determination of SSa/Ro and $\mathrm{SSb} / \mathrm{La}$ autoantibodies, salivary scintigraphy, salivary minor glands biopsy and the ophthalmologic tests including Schirmer e Lissamine green test ().

Patients were assigned, using a random number sequence, to 2 groups and assessed at baseline (T0), after 9 weeks of treatment (T1) and after 9 weeks of follow up (T2).

The 20 patients of interventional group were treated for 9 weeks twice a week (each session lasting 1 hour) with a combined four steps procedure of connective tissue massage [19-21] during the first 10 minutes, Kabat's method [21,22] for about 15 minutes and kinesitherapy for the following 15 minutes. Due to the stressful work of this combination of physiotherapy, the remaining 20 minutes was employed to perform relaxing exercise. All the patients applied also a home program of mimic exercises $[6,12,23]$. Control group (20 patients) performed for 9 weeks a program of daily home exercises for the face only $[6,12,23]$.

In both groups, the home program of mimic exercises was continued after the assessment at the end of the treatment (T1) for further 9 weeks till the end of follow-up (T2), for a total duration of 18 weeks.

None of the patients was edentulous and none presented mandibular osteolysis at X rays.

All patients continued their pharmacological treatments (alprostadil- $\alpha$-cyclodextran, calcium channel blockers, topical glyceryl trinitrate, proton pump inhibitors, clebopride, steroids, cyclophosphamide, azathioprine, methotrexate) with no changes throughout the study. 


\section{Rehabilitation Techniques}

Connective tissue massage is a manual technique used to treat altered connective tissues, in order to increase local blood flow and the release of involved tissue by connective tissue stretching [1921]. For the facial involvement of SSc is strictly recommend to treat not only the face but also the neck [Fig. 1a] and the clavear regions. [Fig. 1b]

Kabat's method is a neurorehabilitation technique that uses spiral and diagonal movement patterns in conjunction with stretch, resistance and other proprioceptive facilitation techniques to reinforce neuromuscular recruitment $[21,22]$. The Kabat's method concern the stimulation of the orbicularis oris [Fig. 1c], zygomaticus [Fig. 1d], levator labii [Fig. 1e], nasalis [Fig. 1f] buccinator [Fig. 2a], frontalis [Fig. 2b,c] and corrugator [Fig. 2d] muscles.

Kinesitherapy consisted in a specific passive, active and assisted exercises for temporalmandibolar joint (exercises for improving mouth opening and jaw lateralizing) [6,12]. [Fig. 2e,f].

Program of home daily exercises. All patients were instructed by the same operator (G.L.) to perform daily of mouth stretching and opening exercises [6,12] and in grimacing exercises for mimic muscles [23] [Fig. 3a-c].Home exercises were divided in three sequences. In the first sequence (to be executed at least 5 minutes, 3 times/day), the patient placed thumbs into the mouth in order to enlarge the oral angles. The movements were done bilaterally and simultaneously (modified from 6). In the second exercise sequence (to be performed once a day) the patient inserted a number (as high as possible) of tongue depressors between the premolars of one arch towards the molars of the controlateral one to properly open the mouth. The tongue depressors should be maintained for a minimum of 8 minutes and, after a stop, the exercise should be repeated, if possible, for additional 8 minutes, by increasing the number of tongue depressors (modified from 6 and 12). The third exercise sequence consisted in mimic exercises to be performed once a day, based on a series of grimaces to exercise (oro)facial muscles [23].

\section{Assessment}

Patients were assessed by the same operator at baseline (T0), at the end of the 9 weeks period of 
treatment (T1) and after 9 weeks of follow-up (T2). The following outcome measures were chosen:

\section{Assessment of global health condition}

Health Assessment Questionnaire disability index (HAQ-DI) [24, 25] was used to measure disability; the Physical Synthetic Index (PSI) and the Mental Synthetic Index (MSI)], of SF36 were used to assess QoL [10, 26, 27].

\section{Face Assessment}

The functional involvement of face and mouth was assessed by the Mouth Handicap in Systemic Sclerosis (MHISS) scale [28] [29].

Mouth opening was assessed in centimeters measuring the distance between the tips of upper and lower right incisive teeth (mean of two consecutive measurements).

Skin involvement of the face was assessed by means of a modified Rodnan skin score[18] to be applied to two areas of the face (right and left cheek).

\section{Statistical Analysis}

Data are presented as mean \pm standard deviation. Student's T test or Mann Whitney tests, when necessary, were used to compare groups characteristics at T0. ANOVA for repeated measures was used for all outcome measures. Data analysis was performed using the SPSS statistical package 12.0 for Windows.

\section{Clinical trial registration}

The study was registered with Current Controlled Trials (www.controlled-trials.com) no ISRCTN43633950.

\section{Results}

The general features of the samples are reported in table 1. No patient dropped out from the study.

\section{$\underline{\text { Assessment of global health condition }}$}


SF36 and HAQ. In both groups, neither the combined treatment nor the home exercise program modified the Physical and Mental Summary Indexes of SF36 and HAQ-DI, as well at the end of the study (T1) and at follow-up (T2) (table 2 and 3).

\section{$\underline{\text { Face assessment }}$}

MHISS scale. In interventional group, the combined treatment significantly improved the scores of MHISS scale at T1 versus T0 (16.25 5.64 vs $17.20 \pm 5.15 ; \mathrm{p}<0.001)$. At T2, MHISS scores

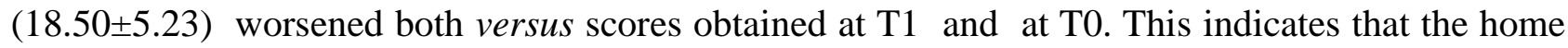
based program did not maintain the effect obtained by the combined program during the previous 9 weeks.

In control group, the home exercise program did not provide any significant change in MHISS throughout the study (table 2 and 3 ).

Mouth opening. Patients of both groups benefited from the treatments for mouth opening. In interventional group, a significant increase of mouth opening was shown at $\mathrm{T} 1$ and still maintained at $\mathrm{T} 2(\mathrm{p}<0.05$ and $\mathrm{p}<0.001$ versus $\mathrm{T} 0$, respectively).

In control group, the home exercise program improved mouth opening at $\mathrm{T} 1$ ( $\mathrm{p}<0.001$ versus $\mathrm{T} 0$ ), but the significance was lost at T2 (table 2 and 3).

Skin score. In interventional group, the combined treatment decreased significantly skin score at T1 ( $\mathrm{p}<0.001$ versus $\mathrm{T} 0)$. The decrease of the skin score was still significant at T2 $(\mathrm{p}<0.01$ versus $\mathrm{T} 0)$. In controls the home exercise program did not modify skin score throughout the study (table 2 and $3)$.

\section{Discussion}

Our data show that, in SSc, a combined rehabilitation approach is significantly more effective than a home exercise program in reducing skin thickness of the face, in recovering mouth opening and in improving self-reported face and mouth related symptoms. It is however clear that the treatment of the face did not exert any effect on global function and QoL. 
SSc leads to fibrosis of facial soft tissues with reduction of mimics and disappearance of the cutaneous furrows. These features, together with diminished mouth opening and width, altered dentition, difficulties in dental intervention, concomitance of sicca syndrome and changes at temporo-mandibular joints often lead to impairment of QoL . In fact, the fibrotic involvement of hands and face becomes one of the SSc patients' greatest complaints [30, 31], with concern about disfigurement [32] and personal self-esteem [33]. It was also shown that, in SSc, skin deformities are a core stressor of the disease, only preceded by fatigue [33].

In order to deal with the facial involvement of SSc patients, we have chosen to use the combination of connective tissue massage (able to modify, by stretching, bloodstream and releasing the connective tissues) and Kabat's method (a neurorehabilitation technique, that reinforces neuromuscular recruitment) [26,27]. These techniques were added to the traditional kinesitherapy and home exercises for mouth and mimic muscles. At the best of our knowledge, this is the first study combining these techniques in a rehabilitation program specifically conceived for the face of SSc patients.

It is interesting to note that the improvement of mouth opening, the only effect of home exercises, was lost at follow up. Contrarily, the effects of combined protocol on mouth opening, skin score and self-perceived functional mouth and face handicap, were maintained after 9 weeks from the end of the study.

This can be due to the efficacy of the different techniques acting sinergically and to the fact that patients continued, for a 9 week period after the end of the treatment, the program of mimic and stretching exercises in a home self management program.

This evidence suggests that the continuity of care is mandatory in the rehabilitation of patients affected with chronic rheumatic diseases, such as SSc, in order to maintain its efficacy [34].

Home exercises for orofacial muscles were of some efficacy. In fact, in the short term period, they were able to increase mouth opening in the group of SSc patients that were assigned to the home program only. 
In the chronic care model, patients are encouraged to become part of the health care team and the concept of self-care or self-management plays a central role [35]. Some evidence exists about the effectiveness of self-management in SSc patients. Recently, Mugii et al studied the efficacy of selfadministered stretching of each finger in SSc patients, showing that amelioration of range of motion was present in each finger after 1 month and maintained within 1 year [36].

The amelioration of MHISS scale suggests that, in SSc, the combined approach improved also the subjective perceptions and the self perceived disability due to face and mouth involvement. This result is important because, although problems related to mouth involvement seem to have less weight than hand related problems in total disability, mouth problems are felt as an important handicap by SSc patients. MHISS is a new scale with an excellent reliability and good construct validity, in the specific assessment of disability involving the mouth in SSc patients [22]. In our study, MHISS was helpful in following-up SSc patients over time for evaluating the outcome due to rehabilitation.

From our data, it is evident that the treatment of the face had no effects on QoL and disability. This is probably due to the relatively short period of the treatment and to the fact that the patients were treated with techniques not aimed to the overall body, but specifically conceived for the involvement of the face.

Due to the complexity and the severity of SSc, the rehabilitation program proposed in the present work should be regarded as a support tool in SSc management. However this combined program should be integrated with global rehabilitation techniques on top of the pharmacological treatments for the disease [4-5].

The limitations of our study may be considered the short period of treatment and follow-up that did not allow us to identify how long the effect of the combined treatment could last after the end of the study.

In conclusion, the combination of Kabat's technique, connective tissue massage and kinesitherapy with home based exercises is effective in the rehabilitative treatment of SSc face. This combination 
treatment may lead to benefits for mouth opening and skin score, maintained also after the end of the program and is more effective than a simple home exercise program. Further studies are needed to evaluate the long term effects of this combined program also in the two SSc subsets.

\section{References}

1. Wigley FM. Systemic Sclerosis: Clinical features. In Klippel JH and Dieppe PA, editors. Rheumatology. London: Mosby; 1998. 7: 9.1-14

2. Casale R, Buonocore M, Matucci-Cerinic M. Systemic sclerosis (scleroderma): an integrated challenge in rehabilitation. Arch Phys Med Rehabil 1997;78:767-73

3. Ranque B, Authier FJ, Berezne A, Guillevin L, Mouthon L. Systemic sclerosis-associated myopathy. Ann N Y Acad Sci 2007;1108:268-82

4. Allanore Y, Avouac J, Wipff J, Kahan A. New therapeutic strategies in the management of systemic sclerosis. Expert Opin Pharmacother 2007;8:607-15

5. Matucci Cerinic M, Del Rosso A, Perfetto F, Livi R, Fiori G, Bartoli F et al. Therapeutic challenges for systemic sclerosis: facts and future targets. Ann N Y Acad Sci 2007;1110:448-54

6. Pizzo G, Scardina GA, Messina P. Effects of a non surgical exercise program on the decreased mouth opening in patients with systemic scleroderma. Clin Oral Investig $2003 ; 7: 175-8$

7. Maddali Bongi S, Landi G, Sigismondi F, Pimpinella F, Miniati I, Conforti ML, et al. Connective massage and Mc Mennel joint manipulation may improve the function of Scleroderma hand. Arthr Rheum 2005; 52 (suppl): 1566

8. Matucci-Cerinic M, Maddali Bongi S, Landi G, Sigismondi F, Conforti ML, Miniati I. Association of Kabat's technique, connective massage and kinesitherapy in the rehabilitative treatment of systemic sclerosis face. International Workshop on Scleroderma, May 18- 20, 
2007, Tokyo, Japan, abstr. 091, page 94

9. Matucci-Cerinic M, Maddali Bongi S, Passalacqua M, Tai G, Bassetti M, Conforti ML, et al. Manual lymph drainage for the treatment of edematous hand in systemic sclerosis. International Workshop on Scleroderma, May 18- 20, 2007, Tokyo, Japan, abstr.046, page 71

10. Del Rosso A, Boldrini M, D'Agostino D, Placidi GP, Scarpato A, Pignone A. Health-related quality of life in systemic sclerosis as measured by the Short Form 36: relationship with clinical and biologic markers. Arthritis Rheum 2004;51:475-81

11. Nagy G, Kovács J, Zeher M, Czirják L. Analysis of the oral manifestations of systemic sclerosis. Oral Surg Oral Med Oral Pathol 1994 ;77:141-6

12. Naylor P, Chester WD, Mix E . The nonsurgical treatment of microstomia in scleroderma: a pilot study. Oral Surg Oral Med Oral Pathol 1984; 57:508-511

13. Cazal C, Sobral AP, Neves RF, Freire Filho FW, Cardoso AB, da Silveira MM.Oral complaints in progressive systemic sclerosis: two cases report. Med Oral Patol Oral Cir Bucal 2008 ;13:E114-8

14. Albilia JB, Lam DK, Blanas N, Clokie CM, Sándor GK. Small mouths ... Big problems? A review of scleroderma and its oral health implications. J Can Dent Assoc 2007;73:831-6

15. Shah AA, Wigley FM. Often forgotten manifestations of systemic sclerosis. Rheum Dis Clin North Am 2008 ;34:221-38; ix

16. Subcommittee for scleroderma criteria of the American Rheumatism Association Diagnostic and Therapeutic Criteria Committee. Preliminary criteria for the classification of systemic sclerosis (scleroderma). Arthritis Rheum 1980;23 :581-90

17. The assessment of the patient with systemic sclerosis. Clin Exp Rheumatol 2003;21(Suppl. 29)

18. Clements P, Lachenbruch P, Seibold J, White B, Weiner S, Martin R, et al. Inter and intraobserver variability of total skin thickness score (modified Rodnan TSS) in systemic 
sclerosis. J Rheumatol 1995;22:1281-5

19. Goats GC, Keir KA. Connective tissue massage. Br J Sports Med 1991;25:131-3

20. Alpiner N, Oh TH, Hinderer SR, Brander VA. Rehabilitation in joint and connective tissue diseases. 1. Systemic Diseases. Arch Phys Med Rehabil 1995; 75: S32-S40

21. Greenman PE. Mobilization with and without impulse technique. 107-112, Principles of Manual Medicine. Philadelphia, ( $3^{\text {rd }}$ edition) Lippincott Williams \& Wilkins 2003.

22. Kabat H, McLeod M, Holt C. The practical application of proprioceptive neuromuscular facilitation. Physiotherapy 1959;45:87-92

23. Kendall FP, Kendall EM, Provance PG. Muscles: functions and test. Lippincott Editor, 2002

24. Johnson SR, Lee P. The HAQ disability index in scleroderma trials. Rheumatology (Oxford) $2004 ; 43: 1200-1$

25. La Montagna G, Cuomo G, Chiarolanza I, Ruocco L, Valentini G. HAQ-DI Italian version in systemic sclerosis. Reumatismo 2006; 58(2):112-5

26. Ware JE, Sherbourne CD. The MOS 36-Item Short Form Health Survey (SF-36): I. Conceptual framework and item selection. Medical Care 1992; 30:473-83

27. Apolone G, Mosconi P: The Italian SF-36 Health Survey: Translation, Validation and Norming. J Clin Epidemiol 1998; 51:1025-36

28. L Mouthon, F Rannou, A Berezne, C Pagnoux, J-P Arene, E Fo1s,et al. Development and validation of a scale for mouth handicap in systemic sclerosis: the Mouth Handicap in Systemic Sclerosis scale. Ann Rheum Dis 2007;66:1651-1655

29. Miniati I, Maddali Bongi S, Del Rosso A, Galluccio F. Matucci-Cerinic M. Mouth Handicap in Systemic Sclerosis scale (MHISS) Italian version. Reumatismo (submitted)

30. Joachim G, Acorn S. Life with a rare chronic disease: the scleroderma experience. J Adv Nurs 2003;42:598-606

31. Benrud-Larson LM, Heinberg LJ, Boling $\mathrm{C}$ et al. Body image dissatisfaction among women with scleroderma: extent and relationship to psychosocial function. Health Psychol 
2003;22:130-9

32. Paquette DL, Falanga V. Cutaneous concerns of scleroderma patients. J Dermatol 2003;30:438-43

33. van Lankveld WGJM, Vonk MC, Teunissen H, van den Hoogen FHJ. Appearance selfesteem in systemic sclerosis - subjective experience of skin deformity and its relationship with physician-assessed skin involvement, disease status and psychological variables. Rheumatology 2007;46:872-876

34. Dagfinrud H, Kvien TK, Hagen KB. Physiotherapy interventions for ankylosing spondylitis. Cochrane Database Syst Rev 2008 Jan 23;(1):CD002822

35. Bodenheimer T, Lorig K, Holman H., Grumbach K. Patient self management of chronic disease in primary care. JAMA 2002 288, 2469-75

36. Mugii N, Hasegawa M, Matsushita T, Kondo M, Orito H, Yanaba K, Komura K, et al. The efficacy of self-administered stretching for finger joint motion in Japanese patients with systemic sclerosis. J Rheumatol 2006;33:1586-92

\section{Legends}

Fig. 1 Physioterapic intervention with connective tissue massage of the neck (a) and clavear region (b). Kabat's technique for the involvement of the orbicularis oris (c) zygomaticus (d) levator labii (e) and nasalis (f) muscles.

Fig. 2 Physiotherapic intervention with Kabat's method for the involvement of buccinators (a) frontalis $(b, c)$ and corrugators (d) muscles. Kinesitherapy for the improvement of mouth opening (e) and jaw lateralizing (f).

Fig. 3 Program of home daily exercises: mouth stretching (a) and mimic exercices (b,c).

Table 1. Patients characteristics.

Table 2. Mean and SD of the items assessed at baseline (T0), at the end of treatment (T1) and after 9 weeks of at follow-up (T2) in interventional group.

Table 3. Mean and SD of the items assessed at baseline (T0), at the end of treatment (T1) and 
after 9 weeks of at follow-up (T2) in control group.

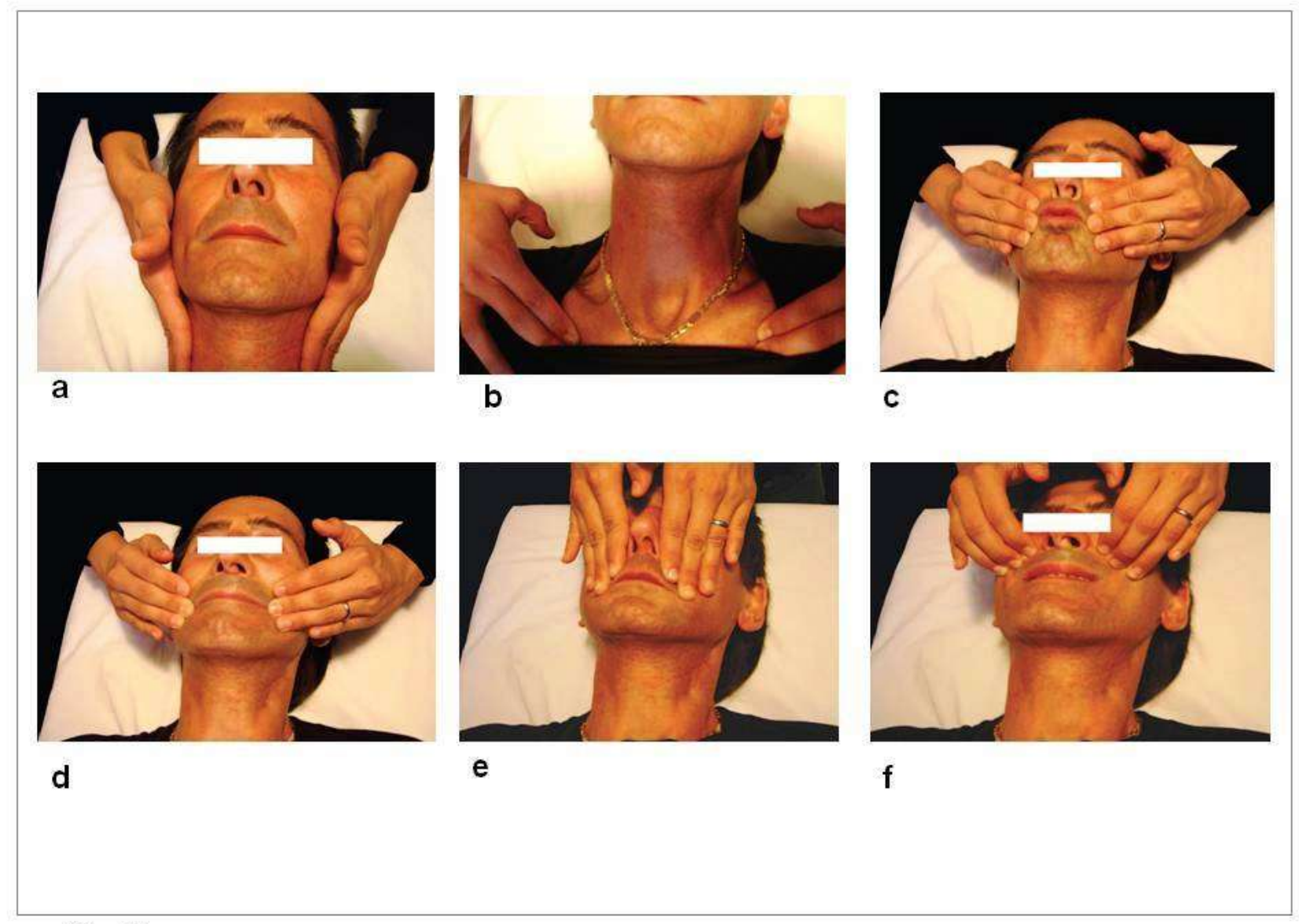

[Fig. 1] 


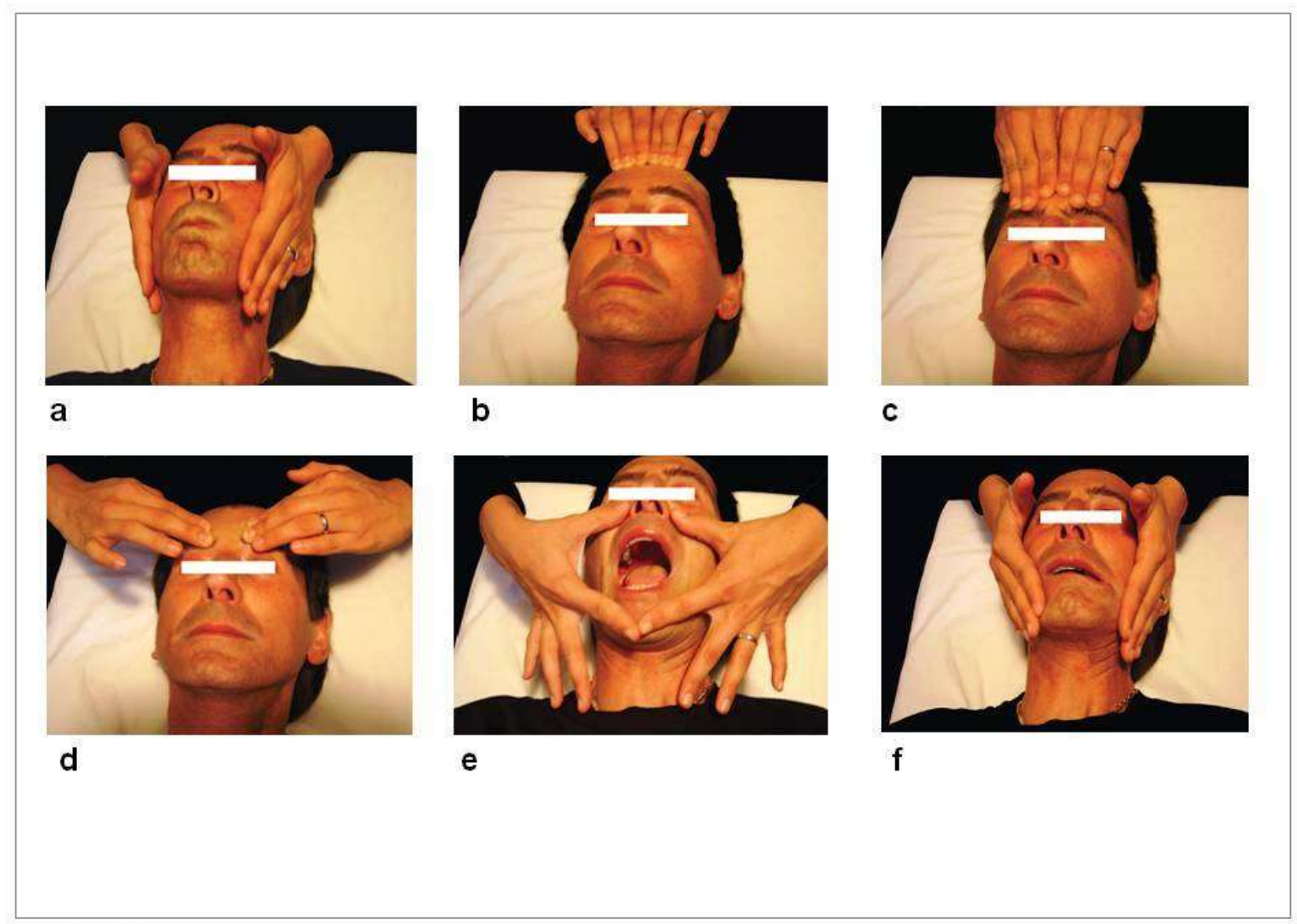

[Fig. 2] 


$$
\frac{\mathrm{e}}{\mathrm{e}}
$$


Patients characteristics

\begin{tabular}{|c|c|c|c|c|}
\hline & SSc patients & Interventional group & Controlgroup & P-value \\
\hline Number & 40 & 20 & 20 & \\
\hline $\operatorname{Sex}(M / F)$ & $6 / 34$ & $2 / 18$ & $4 / 16$ & NS \\
\hline Age (years) & $57.28 \pm 11.33$ & $57.20 \pm 10.23$ & $57.35 \pm 12.60$ & NS \\
\hline Disease duration (years) & $9.4 \pm 43$ & $9.7 \pm 42$ & $9.1 \pm 46$ & NS \\
\hline Active ulcers & 11 & 6 & 5 & NS \\
\hline Raynaud & 40 & 20 & 20 & NS \\
\hline Oesophageal involvement & 13 & 5 & 8 & NS \\
\hline Muscle-skeletal involvement & 16 & 8 & 8 & NS \\
\hline \multicolumn{5}{|l|}{ Lung involvement } \\
\hline ILD & 21 & 11 & 10 & NS \\
\hline PAH & 15 & 7 & 8 & NS \\
\hline Sjögren syndrome & 25 & 13 & 12 & NS \\
\hline MSI (SF-36) & $39.01 \pm 9.12$ & $37,19 \pm 8,03$ & $40,79 \pm 10,35$ & NS \\
\hline PSI (SF-36) & $37.30 \pm 8.12$ & $38,15 \pm 7,89$ & $36,50 \pm 8,39$ & NS \\
\hline HAQ-DI & $0.40 \pm 0.53$ & $0,50 \pm 0,72$ & $0,31 \pm 0,34$ & NS \\
\hline Mouthopening (cm) & $3.90 \pm 1.07$ & $3,80 \pm 1,06$ & $4,00 \pm 1,09$ & NS \\
\hline Facial skin score & $3.72 \pm 1.49$ & $3,90 \pm 1,55$ & $3,55 \pm 1,43$ & NS \\
\hline MHISS & $17.65 \pm 5.25$ & $17.20 \pm 5.15$ & $18.10 \pm 5.36$ & NS \\
\hline
\end{tabular}

[Table 1] Legend: ILD: interstitial lung disease; PAH: pulmonary hypertension MSI = Mental Synthetic Index; PSI =Physical Synthetic Index; HAQ-DI= Health assessment questionnaire disease index, MHISS: Mouth Handicap in Systemic Sclerosis scale 
Mean and SD of the items assessed at baseline (T0), at the end of treatment (T1) and after 9 weeks of at follow-up $(\mathrm{T} 2)$ in interventional group.

\begin{tabular}{|c|c|c|c|c|c|}
\hline & T0 & $\mathrm{T} 1$ & $\mathrm{~T} 2$ & T0-T1 & $\mathrm{T} 0-\mathrm{T} 2$ \\
\hline & Mean \pm SD & Mean \pm SD & $\operatorname{Mean} \pm \mathrm{SD}$ & $p$ & $p$ \\
\hline MSI(SF-36) & $37,19 \pm 8,03$ & $41,01 \pm 7,09$ & $39,22 \pm 6,38$ & NS & NS \\
\hline PSI(SF-36) & $38,15 \pm 7,89$ & $39,58 \pm 7,84$ & $41,99 \pm 6,97$ & NS & NS \\
\hline HAQ-DI & $0,50 \pm 0,72$ & $0,24 \pm 0,29$ & $0,16 \pm 0,09$ & NS & NS \\
\hline Mouth opening $(\mathrm{cm})$ & $3,80 \pm 1,06$ & $4,28 \pm 0,99$ & $4,58 \pm 1,16$ & $\mathrm{p}<0.05$ & $\mathrm{p}<0.001$ \\
\hline Skin score & $3,90 \pm 1,55$ & $1,60 \pm 0,99$ & $1,75 \pm 1,02$ & $\mathrm{P}<0.001$ & $\mathrm{P}<0.001$ \\
\hline MHISS & $17.20 \pm 5.15$ & $16.25 \pm 5.64$ & $18.50 \pm 5.23$ & $\mathrm{P}<0.001$ & NS \\
\hline
\end{tabular}
[Table 2] $\begin{aligned} & \text { Legend }: \text { MSI =Mental Synthetic Index; PSI =Physical Synthetic Index; HAQ-DI= Health assessment questionnaire disease index; : Mouth Handicap } \\ & \text { insystemic Sclerosis scale. }\end{aligned}$ 
Mean and SD of the items assessed at baseline (T0), at the end of treatment (T1) and after 9 weeks of at follow-up (T2) in control group.

\begin{tabular}{|c|c|c|c|c|c|}
\hline & To & $\mathrm{T} 1$ & $\mathrm{~T} 2$ & $\mathrm{~T} 0-\mathrm{T} 1$ & $\mathrm{~T} 0-\mathrm{T} 2$ \\
\hline & Mean $\pm S D$ & Mean $\pm S D$ & Mean $\pm S D$ & $p$ & $p$ \\
\hline $\mathrm{MSI}(\mathrm{SF}-36)$ & $40,79 \pm 10,35$ & $40,98 \pm 7,96$ & $41,93 \pm 11,42$ & NS & NS \\
\hline PSI (SF-36) & $36,50 \pm 8,39$ & $35,81 \pm 7,87$ & $37,52 \pm 8,35$ & NS & NS \\
\hline HAQ-DI & $0,31 \pm 0,34$ & $0,33 \pm 0,31$ & $0,26 \pm 0,20$ & NS & NS \\
\hline Mouth opening $(\mathrm{cm})$ & $4,00 \pm 1,09$ & $4,48 \pm 1,04$ & $4,20 \pm 1,05$ & $p<0.001$ & NS \\
\hline Skinscore & $3,55 \pm 1,43$ & $3,15 \pm 1,63$ & $3,35 \pm 1,18$ & NS & NS \\
\hline MHISS & $18.10 \pm 5.36$ & $18.00 \pm 4.97$ & $17.90 \pm 4.03$ & NS & NS \\
\hline
\end{tabular}
[Table 3] Legend: MSI = Mental Synthetic Index; PSI=Physical Synthetic Index; HAQ-DI=Health assessment questionnaire disease index; Mouth Handicap in
Systemic Sclerosis scale. 